\title{
DEMATEL Technique to Assess Social Capital Dimensions on Consumer Engagement Effect on Co-Creation
}

\author{
Angela Abena Nusenu*, Wen Xiao, Christian Narh Opata, Deborah Darko \\ School of Management and Economics, University of Electronic Science and Technology of China, Chengdu, China \\ Email: ^angelaankrah@yahoo.com, xiaowen@uestc.edu.cn, chrisrui@yahoo.com,debborahdarko1234@yahoo.com
}

How to cite this paper: Nusenu, A.A., Xiao, W., Opata, C.N. and Darko, D. (2019) DEMATEL Technique to Assess Social Capital Dimensions on Consumer Engagement Effect on Co-Creation. Open Journal of Business and Management, 7, 597-615. https://doi.org/10.4236/ojbm.2019.72041

Received: February 16, 2019

Accepted: March 29, 2019

Published: April 1, 2019

Copyright (อ 2019 by author(s) and Scientific Research Publishing Inc. This work is licensed under the Creative Commons Attribution International License (CC BY 4.0).

http://creativecommons.org/licenses/by/4.0/

\begin{abstract}
The concept of social capital has become an interesting issue in management literature. Several authors have called for more study to be carried out on the dimensions of social capital. As part of the response to this call, we examined the influence of the dimensions of social capital on customer engagement to co-create. The Decision-Making Trial and Evaluation Laboratory (DEMATEL) technique was applied to analyze and capture the causal relationship visibly among the criteria and also measure the interaction level and the direction of influence of the criteria. The criteria identified to be crucial in influencing other criteria to co-create and the driving factors for problem-solving were: commitment (b8), Shared code and language (c9), shared narratives (c10), consumer engagement (d11), density (a3) and structural holes (a5). Criteria such as frequency of interaction (b7), trust (b6), social interaction (a4) and network ties were recognized as the core subjects that need maximum attention because they are effect-type attributes and cannot be directly improved unless through other criteria.
\end{abstract}

\section{Keywords}

Social Capital, Dimensions, Consumer Engagement, Co-Creation Task, Decision-Making Trial and Evaluation Laboratory, DEMATEL

\section{Introduction}

This world is viewed as a global village full of interconnected networks between and among countries, regulatory bodies, related institutions, cooperative and competitive firms, suppliers, customers, and other stakeholders. These entities are all embedded in a well-coordinated network of interactions which has led to 
the formation of interconnected patterns [1].

Over the years, detailed studies in the field of social networks and the concept of social capital were brought into play, together with the knowledge of economics to demonstrate how rational individual or groups engage in purposive action [2] [3]. According to [4], Social capital is "the sum of the actual and potential resources embedded within, available through, and derived from the network of relations possessed by an individual or social unit". The concept involves resources residing in the ties between people and among people and networks. Social capital has become one of the most popular concept drawn from sociological theory into other fields-political science [5] [6], psychology [7] [8] [9] and economics [10] [11] [12]. Studies have shown it desirable effects on a wide range of social life, for instance educational attainment, community development, crime reduction, governance, health and knowledge exchange. Additionally, economic benefits such as career success, enhance job search effectiveness, facilitate resource exchange, reduce transaction costs and employee turnover, minimize redundancy, increase efficiency, induce information flow, enhance creativity and innovation, at all levels of society [4] [13] [14] [15] [16]. For decades now, the concept has been exported into management literature as a source of value creation generating an interdisciplinary exchange of new insight and scope-a significant subject for firms [17] [18]. Existing studies have shown the strategic role of social capital to firms due to its positive outcome on value creation [4] [17] [19]. [4] points out the dimensions of social capital involving structural social capital, relational social capital and cognitive social capital. These dimensions are essential to consider for their impact on value creation. [20] argued that the dimensions of social capital have a profound influence on the success of value creation. The relation between the dimensions of social capital and value creation is significant for understanding why positions and relations in a network motivate for meaningful participation in value creation. The connections between and among actors that generate into meaningful participation for value creation are formed because they share in the same event which generates mutual benefits. The network of relation forms a basis for leveraging a variety of resources for firms-enhanced learning, innovation, reduction in research and development $(R \& D)$ cost, promoting relations and ties to other actors within the network hence, higher chances of firm's survival. For projects concerned, studies have shown decreases in transaction costs and improved project management. For individuals and other stakeholders involved, a sign of potential increases associated with high performing projects and exposure to knowledge and knowledge exchange [17] [21] [22] [23] [24].

Though existing studies have established a relationship between social capital and value creation, yet they involve little about the application of DEMATEL to identify the dimensions that act as problem-solving drivers for value co-creation related issues and also to clarify the dimensions that need maximum attention to enhance value creation. Based on these the main contributions of this paper is 
can be highlighted as follows:

- Provide an overall framework of the influence of the dimensions of social capital on consumer engagement to a co-creation task.

- Introduce and elaborate on the concept of Decision-Making Trial and Evaluation Laboratory (DEMATEL) technique.

- Use DEMATEL technique efficiency to identify the importance and causal relationships between the dimensions of social capital on consumer engagement to co-create.

\section{Literature Review}

\subsection{Social Capital}

In social structure literature, social capital has been proposed as one of the most useful concepts that provide theoretical and procedural perspectives to examine important features in the social context of the firm-consumer relationship [3] [20]. The firm cannot be studied within an independent context because its inception was built on social relations where every economic action undertaking and its corresponding outcome were rooted in the social structure. Drawing on this view, it is clearly understood that every economic activity is ingrained in social relations and it's greatly affected by actors' relations and the overall structure of the network of relations.

The conceptual foundation to stem up the definition of social capital seems blur due to the absence of unanimity in the different view-point of great thinkers such as [5] [21] [22] [25] [26] [27] [28] [29], [30] who inspired most of the current works in social capital. However, based on the work of the aforementioned authors [4] definition of social capital gives an explicit picture of social capital as a "joint asset" that upsurges the efficiency of a community in the resources exchange that occur in it [25]. Furthermore, from a community point of view, it increases cooperation, adjustment and the productive value of social connection for the mutual benefit of its members relevant to the objective of the social organization [31] [32] [33].

Conventionally, firms were assumed to be linked to its consumers by an arms-length relationship and pursue self-interested and profit-seeking agenda without any explicit consideration for firm-consumer relations. Any ongoing relationship existing between them was believed to be profit-seeking motivated [16]. [29], couldn't have put it better by stating that firms are not just made up of many discrete units that make self-centered decisions constrained by scarce resources anymore, but rather, how embedded they are in a network of relations determine their strategic conduct.

Examining the relationship of social capital on the creation of intellectual capital by [4], clarified the dimensions of social capital as: structural, relational and cognitive. The author's discussion on the structural and relational dimensions of social capital was mostly based on the argument of [3] [16]. Where the structural dimension described the tie architecture and exchange pattern between and 
among actors within a network which is mostly characterized by the size of the network, density, centrality, frequent communication. The relational dimension emphasized personal relationships developed by actors through a history of interactions with important features such as trustworthiness and trust [34] [35]. The last dimension of social capital, cognitive, focuses on the system of meaning-shared representations and interpretations with focal features of shared code and language, and shared narratives [4] [36] [37].

\subsection{Value Creation and Value Co-Creation}

Based on the production-oriented perspectives, the idea of value creation can be traced back to the early $20^{\text {th }}$ century industry principle, where the value chain concept introduced by Michael Porter in the 1980s gave the firm an integrated framework to identify, manage the cost of designing, producing, marketing, delivering and supporting goods and services. Value creation was predominantly the responsibility of the firm which occurred inside the firm through its activities in that the firm strongly believed its competitive edge of ability to innovate and placing more emphasis on value delivery [38] [39] [40].

As showed by [41], value is internally produced and distributed in the marketplace, through the exchange of goods/services, and money, and without any direct interference by customers. This conventional concept about value creation can be identified as the backbone of the goods-dominant logic (G-D logic) view, where value is embedded into the product of economic exchange during the firm's production process and is delivered to be sold. The value of the good signifies the market price the consumer is willing to pay.

Literature is silent on the actual definition of value creation and blurs on the distinction between value creation and value co-creation [42] [43]. The concept is generally treated as co-creation, emphasizing the inclusive activities by both the firm and the customer [40] [43] [44]. Its explanation has a strong association with the service-dominant logic (SDL) which states that always, value is co-created with the client-customers role is to be the value creator and perhaps also a value co-creator [39]. Viewing value creation and co-creation from the SDL put the firm in charge of value creation and the consumer is called to join in the whole activity of creating as a co-creator [45]. This leads to a web of interconnections with consumers and other stakeholders where the "we" proposition becomes much broader and powerful than just "I" and "you." in value creation [46] (Figure 1 and Table 1).

\subsection{Social Capital Shaping Consumer Engagement to Co-Create}

In examining the relationship among parties involved in value creation, the concept of social capital make available valuable and extensive view for understanding the role of its dimensions on consumer involvement in value creation [50] [64]. According to [4], the concept is central to the understanding of institutional dynamics, innovation and most importantly value creation. Reviewing 


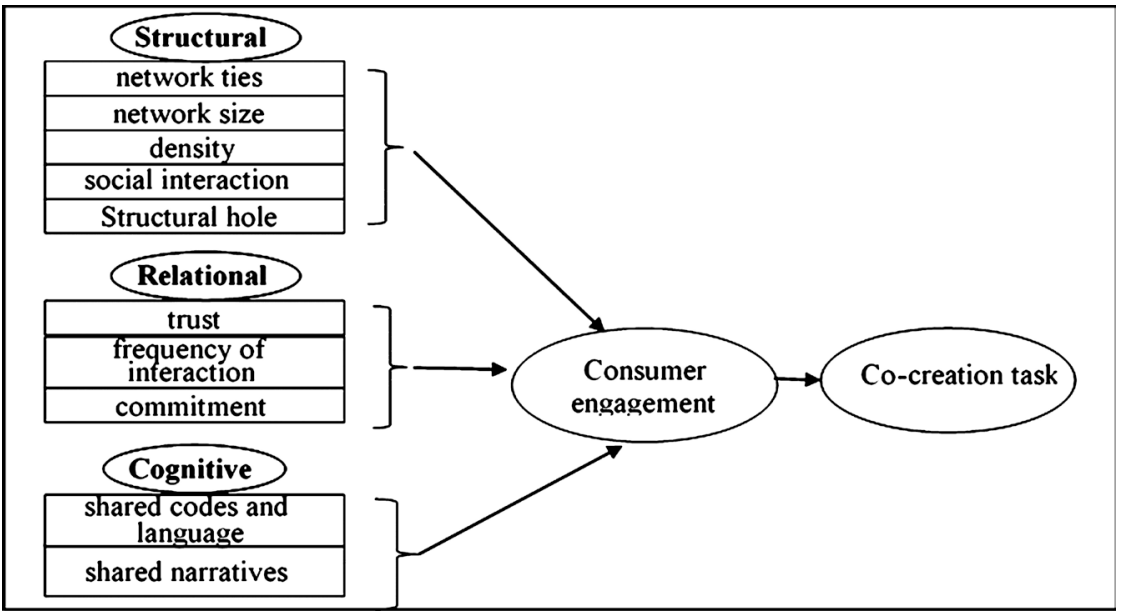

Source: Own study.

Figure 1. Construct model of social capital dimensions on consumer engagement to co-create.

related works on consumer engagement, authors such as [60] [65] [66] [67] claimed that consumer engagement is made up of both transactional and non-transactional behavior exhibited when consumers are in interaction with a brand, organization and/or co-created customer experience with other stakeholders. The value of social capital on consumer engagement is evident in the consumers' willingness to share experiences, competencies, and expertise, exchange tacit information, demonstration of higher disposition to take risks, and having greater openness to create value developed through trust, close bonding and affinity with others within the social structure [2] [15] [20] [52] [60] [64] [68] [69]. The bond or connections that generate among these exchange partners (consumers) within a social structure serve as a drive to gain complementary know-how and/or speed up R\&D processes to accomplish co-creation task [70]. Literature is explicit on the assumption that similarity of partners participating in the same event is beneficial for idea generation, speedy dissemination of information among partners thereby enhancing efficiency and cooperation that support value creation [51]. The network partners involved can create value through their engagement via frequent interactions to motivate and create solidarity benefits [14]. According to [2], solidarity benefits and valuable information supporting value creation are associated with strong ties as opposed to the argument of both [16] [64] that new and valuable information to create value occurs by bridging weak ties. Supported works from [57] [71] indicates that successful transfer of new information via stronger ties are possible because of structural bridging qualities and the willingness of actors to cooperate due to relational qualities. Again, [72], shows that the strength of strong ties in the creation of value for consumers makes it possible to combine the solidarity benefits of strong ties with the new and valuable information generated and the benefits of weak ties in value creation. While Coleman's and Burt's views on social capital are seen differently because they analyze different features of the social system, both views complement each other in that strong ties (quality of relationships) with 
Table 1. Summary of authors' viewpoint on the criteria for analysis.

\begin{tabular}{|c|c|c|}
\hline Social Capital Dimensions & Authors & Description \\
\hline \multicolumn{3}{|l|}{ Structural (A) } \\
\hline Network ties $\left(a_{1}\right)$ & {$[4][47][48][49]$} & $\begin{array}{l}\text { The pattern of connection between actors i.e. Who you reach and how they are reached. } \\
\text { Identified as an information-carrying connections between and among actors/people on a } \\
\text { network. }\end{array}$ \\
\hline Network size $\left(\mathrm{a}_{2}\right)$ & {$[50]$} & $\begin{array}{l}\text { The Number of actors (individuals or group) within the network i.e. the total number of } \\
\text { contacts an actor has in its network and one of the most studied variables of social capital. A } \\
\text { large network size means a large number of people an actor interacts with. }\end{array}$ \\
\hline Density $\left(a_{3}\right)$ & [2] [50] [51] [52] & $\begin{array}{l}\text { The degree of interconnection among the actors of a network. Possible connections in a } \\
\text { network that are actual connections. Density propagate network cohesion and partners } \\
\text { connectedness leading to high-quality and easy information distribution in a dense network. }\end{array}$ \\
\hline Social interaction $\left(a_{4}\right)$ & [19] [47] [53] [54] & $\begin{array}{l}\text { Information exchange and resource flow among actors within a network through network } \\
\text { ties. Also refers to the interaction with other customers who participate in economic } \\
\text { transactions with a firm }\end{array}$ \\
\hline Structural holes $\left(a_{5}\right)$ & {$[55][56]$} & $\begin{array}{l}\text { Lack of connection between actors within a network. This lack of disconnection between } \\
\text { actors exposes them to new networks with diverse experiences and different ideas, which } \\
\text { offers them (actors) superior information, opportunities and the possibility of manipulating } \\
\text { information flow between disconnected parties for their benefits }\end{array}$ \\
\hline
\end{tabular}

Relational(B)

Trust $\left(\mathrm{b}_{6}\right)$

Frequency of interaction $\left(b_{7}\right) \quad[36][51][57]$

Commitment $\left(b_{8}\right)$

\section{Cognitive (C)}

Shared code and language $\left(c_{9}\right) \quad$ [4] [36] [53]

Shared Narratives $\left(c_{10)}\right.$

Actor's Involvement (D)

Consumer Engagement $\left(\mathrm{d}_{11}\right)$

[35] [59] [60] [61] Involvement of the consumer by virtue of task-related and personal interaction with network actors. Transactional and non-transactional behavior exhibited when consumers are in interaction with a brand, organization and/or co-created customer experience with other stakeholders

Value Creation Activity (E) [62] [63]
The confidence actors have in one another that create the conditions for successful information exchange and resource flow.

The rate or regularity of exchange among actors. Interacting frequently has been found to create some sort of norms of reciprocity and relationship-specific investigations that make it easier for information sharing between firms and their clients

A sense of duty, obligation and responsibility to engage in an action that arises from frequent interaction leading to a value generating object.

How actors organize, understand, discuss, ask questions and exchange information within a common language to facilitate the ability to gain access to other actors and information.

All those stories and metaphors that support persuasive arguments and conclusive proof of good ideas and its exchange and sharing.

weak structural positions (structural holes and network position) bring to light the most intriguing value creating ideas with the most ground-breaking solutions. Information from one partner to another is directly influenced by the strength of their relationship. However, the value of the information may be higher if it is received from weak ties. In substantiating [52] [60] arguments, [64], stated that network ties preferably strong ties have a stronger association 
with value creation because information moves faster and is more credible due to its rapid and reflected actions. Implying, weak network configuration without strong ties have no value: they lead to no action.

\section{Methodology}

\subsection{DEMATEL Technique}

DEMATEL is one of the most widely accepted and beneficial techniques to measure and analyze structural models relating to cause-effect relationships and the interdependence among complex testing criteria [73]. These relations among the evaluating criteria is supported by numerical values representing the strength of influence. The technique aids in understanding the structural relations among elements and help solve complicated system problems [74].

In the sphere of human activities of decision making and management characterized by uncertainties and complexity, it is important that suitable established models are chosen in accordance with the problem at hand so that an in-depth analysis into the nature of the problem can be conducted. This makes DEMATEL the appropriate model to be used since it works with specific features of objective affairs to confirm the relationship and ascertain the interdependence among variables [75]. DEMATEL has been applied in many areas including supply chain management [76] [77] [78] [79], Education [75] [80] [81], Health [73] [82], innovation policies in small and medium-scale enterprises (SME's), barriers to entrepreneurship and facility prioritization [83] [84] [85]. Moreover, the DEMATEL technique has been used in combination with other methods such as fuzzy, failure mode and effects analysis (FMAE), technique for order preference by similarity to ideal solution (TOPSIS), analytic network process (ANP) and analytic hierarchy process (AHP), VIseKriterijumska Optimizacija I Kompromisno Resenje (VIKOR) for evaluating the spare-part industry [80], reliability allocation [86], e-learning evaluation [87], product concept evaluation [88] and innovation support system for higher education [89]. As part of this study, the DEMATEL was used to determine the multifaceted relationships and the level of influence each element has on others.

\subsection{DEMATEL Method Application}

Building on the opinions of ten experts, ten (10) sub-dimensions of social capital were analyzed: network ties $\left(a_{1}\right)$, size of the network $\left(a_{2}\right)$, density $\left(a_{3}\right)$, social interaction $\left(a_{4}\right)$, structural holes $\left(a_{5}\right)$, trust $\left(b_{6}\right)$, frequency of interaction $\left(b_{7}\right)$, commitment $\left(b_{8}\right)$, shared codes and language $\left(c_{9}\right)$. Shared narratives $\left(c_{10}\right)$. Then, consumer engagement $\left(\mathrm{d}_{11}\right)$, and co-creation task $\left(e_{12}\right)$. The experts were called on to examine the level of relationship these sub-dimensions have on consumer engagement to a co-create task. The experts included university professors, social network analyst and Ph.D. candidates whose research area are centered on the study in question. The formulating steps of the technique summarized as follows: 
Step 1: Scale definition.

The influence scale is defined to show the impact level of the criterion. For this study, the values for the influence score ranges from 0 to 4 . Where $0=$ no effect, 1 = low effect, $2=$ moderate effect, $3=$ high effect and $4=$ very high effect.

Step 2: Construct a relationship matrix

An assembly of experts and factors were used in this step. Each individual assessor is requested to evaluate the level of direct influence between two criteria in a pair-wise comparison including the consumer engagement and the co-creation task. In so doing a direct-relation table was created which was symbolized as $x i j$ signifying the degree to which the experts view factor $i$ effects on factor $j$. All the diagonal elements are zero $(0)$.

$$
A=\left[\begin{array}{ccccc}
0 & a_{12} & a_{13} & \cdots & a_{1 n} \\
a_{21} & 0 & a_{23} & \cdots & a_{2 n} \\
a_{31} & a_{32} & 0 & \cdots & a_{3 n} \\
\vdots & \vdots & \vdots & \ddots & \vdots \\
a_{n 1} & a_{n 2} & a_{n 2} & \cdots & 0
\end{array}\right]
$$

Afterward, the judgments from experts are all aggregated to attain the average matrix $A=\left[a_{i j}\right]$ indicated in Table 2. The aggregated matrix $A$ was built using Equation (1).

$$
A_{i j}=\frac{1}{e} \sum_{i=1}^{e} a_{i j}^{m}
$$

where, $e=$ total number of experts, $m=$ individual expert.

Step 3: Normalise the matrix.

In applying Equation (2) and (3), a normalized matrix $A$ was constructed on the bases of the column vector and the maximum value (Table 3 ).

Table 2. Average matrix $A$.

\begin{tabular}{ccccccccccccc}
\hline $\mathrm{n}$ & $\mathrm{a}_{1}$ & $\mathrm{a}_{2}$ & $\mathrm{a}_{3}$ & $\mathrm{a}_{4}$ & $\mathrm{a}_{5}$ & $\mathrm{~b}_{6}$ & $\mathrm{~b}_{7}$ & $\mathrm{~b}_{8}$ & $\mathrm{c}_{9}$ & $\mathrm{c}_{10}$ & $\mathrm{~d}_{11}$ & $\mathrm{e}_{12}$ \\
\hline $\mathrm{a}_{1}$ & 0 & 4 & 3 & 23 & 9 & 21 & 25 & 22 & 2 & 5 & 18 & 2 \\
$\mathrm{a}_{2}$ & 8 & 0 & 17 & 20 & 10 & 20 & 17 & 16 & 1 & 3 & 16 & 1 \\
$\mathrm{a}_{3}$ & 18 & 26 & 0 & 26 & 17 & 25 & 24 & 24 & 3 & 4 & 15 & 4 \\
$\mathrm{a}_{4}$ & 18 & 15 & 19 & 0 & 13 & 21 & 24 & 19 & 11 & 14 & 22 & 7 \\
$\mathrm{a}_{5}$ & 20 & 17 & 14 & 23 & 0 & 18 & 29 & 2 & 16 & 18 & 21 & 4 \\
$\mathrm{~b}_{6}$ & 16 & 13 & 15 & 17 & 13 & 0 & 26 & 23 & 11 & 19 & 15 & 1 \\
$\mathrm{~b}_{7}$ & 19 & 24 & 17 & 24 & 13 & 25 & 0 & 20 & 14 & 16 & 23 & 8 \\
$\mathrm{~b}_{8}$ & 20.5 & 24 & 20 & 24 & 16 & 24 & 23 & 0 & 22 & 24 & 15 & 5 \\
$\mathrm{c}_{9}$ & 25 & 21 & 20 & 22 & 17 & 21 & 26 & 28 & 0 & 25 & 20 & 10 \\
$\mathrm{c}_{10}$ & 21 & 19.5 & 19 & 24 & 15 & 22 & 31 & 22 & 26 & 0 & 19 & 5 \\
$\mathrm{~d}_{11}$ & 20 & 14 & 13 & 22 & 17 & 18 & 22 & 12 & 18 & 20 & 0 & 36 \\
$\mathrm{e}_{12}$ & 8 & 8 & 7 & 24.5 & 9 & 11 & 30 & 18 & 17 & 15 & 21 & 0 \\
\hline
\end{tabular}

Source: Own study. 
Table 3. Normalized matrix.

\begin{tabular}{cccccccccccccc}
\hline $\mathrm{n}$ & $\mathrm{a}_{1}$ & $\mathrm{a}_{2}$ & $\mathrm{a}_{3}$ & $\mathrm{a}_{4}$ & $\mathrm{a}_{5}$ & $\mathrm{~b}_{6}$ & $\mathrm{~b}_{7}$ & $\mathrm{~b}_{8}$ & $\mathrm{c}_{9}$ & $\mathrm{c}_{10}$ & $\mathrm{~d}_{11}$ & $\mathrm{e}_{12}$ \\
$\mathrm{a}_{1}$ & 0.000 & 0.014 & 0.011 & 0.083 & 0.032 & 0.076 & 0.090 & 0.079 & 0.007 & 0.018 & 0.065 & 0.007 \\
$\mathrm{a}_{2}$ & 0.029 & 0.000 & 0.061 & 0.072 & 0.036 & 0.072 & 0.061 & 0.058 & 0.004 & 0.011 & 0.058 & 0.004 \\
$\mathrm{a}_{3}$ & 0.065 & 0.094 & 0.000 & 0.094 & 0.061 & 0.090 & 0.087 & 0.087 & 0.011 & 0.014 & 0.054 & 0.014 \\
$\mathrm{a}_{4}$ & 0.065 & 0.054 & 0.069 & 0.000 & 0.047 & 0.076 & 0.087 & 0.069 & 0.040 & 0.051 & 0.079 & 0.025 \\
$\mathrm{a}_{5}$ & 0.072 & 0.061 & 0.051 & 0.083 & 0.000 & 0.065 & 0.105 & 0.007 & 0.058 & 0.065 & 0.076 & 0.014 \\
$\mathrm{~b}_{6}$ & 0.058 & 0.047 & 0.054 & 0.061 & 0.047 & 0.000 & 0.094 & 0.083 & 0.040 & 0.069 & 0.054 & 0.004 \\
$\mathrm{~b}_{7}$ & 0.069 & 0.087 & 0.061 & 0.087 & 0.047 & 0.090 & 0.000 & 0.072 & 0.051 & 0.058 & 0.083 & 0.029 \\
$\mathrm{~b}_{8}$ & 0.074 & 0.087 & 0.072 & 0.087 & 0.058 & 0.087 & 0.083 & 0.000 & 0.079 & 0.087 & 0.054 & 0.018 \\
$\mathrm{c}_{9}$ & 0.090 & 0.076 & 0.072 & 0.079 & 0.061 & 0.076 & 0.094 & 0.101 & 0.000 & 0.090 & 0.072 & 0.036 \\
$\mathrm{c}_{10}$ & 0.076 & 0.070 & 0.069 & 0.087 & 0.054 & 0.079 & 0.112 & 0.079 & 0.094 & 0.000 & 0.069 & 0.018 \\
$\mathrm{~d}_{11}$ & 0.072 & 0.051 & 0.047 & 0.079 & 0.061 & 0.065 & 0.079 & 0.043 & 0.065 & 0.072 & 0.000 & 0.130 \\
$\mathrm{e}_{12}$ & 0.029 & 0.029 & 0.025 & 0.088 & 0.032 & 0.040 & 0.108 & 0.065 & 0.061 & 0.054 & 0.076 & 0.000 \\
\hline
\end{tabular}

Source: Own study.

$$
\begin{gathered}
Q=\frac{1}{\max _{1 \leq i \leq n}\left(\sum_{j}^{n} a_{i j}\right)} \\
N=Q X
\end{gathered}
$$

Step 4: Construct a total relations matrix.

Total relations matrix $T$ was constructed by using Equation (4). By doing so, the overall strength of influence and effect from other criteria are determined.

$$
T=D+D^{2} D^{3}+D^{n}=D(I-D)^{(-1)}, n \rightarrow \infty
$$

Step 5: Compute the sum of the rows and column in matrix $T$, to obtain the total values for $C$ and $R$ using Equations (5) and (6). Where $C$ signifies the level of direct or indirect effects on other criteria, and $\mathrm{R}$, the level to which it is affected by other criteria: (Table 4)

$$
\begin{gathered}
C_{i}=\sum_{j=1}^{n} t_{i j} \\
R_{i}=\sum_{j=1}^{n} t_{i j} \\
T=\left[t_{i j}\right], i, j=(1,2,3, \cdots, n)
\end{gathered}
$$

Step 6: Compute a threshold value by averaging the elements in matrix $T$. This is to help do away with minor effects in the matrix $T$ elements with the intention of minimizing the complexity of the impact relations-map. If the influence level of an element in the matrix $T$ is higher than the threshold value then the element is included in the influence relations map (IRM) (Table 5, Table 6 and Figure 2). 
Table 4. Total influence matrix (T).

\begin{tabular}{ccccccccccccc}
\hline $\mathrm{n}$ & $\mathrm{a}_{1}$ & $\mathrm{a}_{2}$ & $\mathrm{a}_{3}$ & $\mathrm{a}_{4}$ & $\mathrm{a}_{5}$ & $\mathrm{~b}_{6}$ & $\mathrm{~b}_{7}$ & $\mathrm{~b}_{8}$ & $\mathrm{~b}_{9}$ & $\mathrm{c}_{10}$ & $\mathrm{~d}_{11}$ & $\mathrm{e}_{12}$ \\
\hline $\mathrm{a}_{1}$ & 0.093 & 0.104 & 0.092 & 0.191 & 0.103 & 0.179 & 0.208 & 0.170 & 0.077 & 0.099 & 0.157 & 0.051 \\
$\mathrm{a}_{2}$ & 0.116 & 1.085 & 0.134 & 0.175 & 0.103 & 0.170 & 0.175 & 0.145 & 0.066 & 0.084 & 0.145 & 0.044 \\
$\mathrm{a}_{3}$ & 0.181 & 0.204 & 1.105 & 0.237 & 0.151 & 0.226 & 0.243 & 0.207 & 0.096 & 0.116 & 0.177 & 0.066 \\
$\mathrm{a}_{4}$ & 0.184 & 0.171 & 0.170 & 1.153 & 0.140 & 0.215 & 0.246 & 0.194 & 0.126 & 0.151 & 0.201 & 0.080 \\
$\mathrm{a}_{5}$ & 0.190 & 0.175 & 0.153 & 0.228 & 1.094 & 0.204 & 0.261 & 0.138 & 0.141 & 0.162 & 0.199 & 0.070 \\
$\mathrm{~b}_{6}$ & 0.173 & 0.158 & 0.152 & 0.201 & 0.135 & 1.137 & 0.242 & 0.199 & 0.122 & 0.162 & 0.173 & 0.055 \\
$\mathrm{~b}_{7}$ & 0.198 & 0.210 & 0.174 & 0.246 & 0.149 & 0.241 & 1.182 & 0.209 & 0.143 & 0.167 & 0.216 & 0.088 \\
$\mathrm{~b}_{8}$ & 0.214 & 0.221 & 0.194 & 0.259 & 0.167 & 0.250 & 0.273 & 1.154 & 0.177 & 0.201 & 0.202 & 0.080 \\
$\mathrm{c}_{9}$ & 0.240 & 0.222 & 0.203 & 0.268 & 0.179 & 0.254 & 0.298 & 0.258 & 1.113 & 0.214 & 0.230 & 0.103 \\
$\mathrm{c}_{10}$ & 0.222 & 0.212 & 0.195 & 0.266 & 0.168 & 0.250 & 0.304 & 0.233 & 0.194 & 1.126 & 0.220 & 0.084 \\
$\mathrm{~d}_{11}$ & 0.206 & 0.181 & 0.164 & 0.249 & 0.166 & 0.223 & 0.267 & 0.190 & 0.164 & 0.186 & 1.148 & 0.184 \\
$\mathrm{e}_{12}$ & 0.147 & 0.142 & 0.127 & 0.227 & 0.123 & 0.175 & 0.258 & 0.184 & 0.145 & 0.153 & 0.194 & 1.056 \\
\hline
\end{tabular}

Source: Own study.

Table 5. Significant direct/indirect matrix (threshold 0.173).

\begin{tabular}{|c|c|c|c|c|c|c|c|c|c|c|c|c|}
\hline $\mathrm{n}$ & $a_{1}$ & $a_{2}$ & $a_{3}$ & $a_{4}$ & $a_{5}$ & $\mathrm{~b}_{6}$ & $b_{7}$ & $\mathrm{~b}_{8}$ & $c_{9}$ & $c_{10}$ & $\mathrm{~d}_{11}$ & $e_{12}$ \\
\hline$a_{1}$ & & & & 0.191 & & 0.179 & 0.208 & & & & & \\
\hline$a_{2}$ & & & & 0.175 & & & 0.175 & & & & & \\
\hline$a_{3}$ & 0.181 & 0.204 & & 0.237 & & 0.226 & 0.243 & 0.207 & & & 0.177 & \\
\hline$a_{4}$ & 0.184 & & & & & 0.215 & 0.246 & 0.194 & & & 0.201 & \\
\hline$a_{5}$ & 0.190 & 0.175 & & 0.228 & & 0.204 & 0.261 & & & & 0.199 & \\
\hline $\mathrm{b}_{6}$ & 0.173 & & & 0.201 & & & 0.242 & 0.199 & & & 0.173 & \\
\hline$b_{7}$ & 0.198 & 0.210 & 0.174 & 0.246 & & 0.241 & & 0.209 & & & 0.216 & \\
\hline $\mathrm{b}_{8}$ & 0.214 & 0.221 & 0.194 & 0.259 & & 0.250 & 0.273 & & 0.177 & 0.201 & 0.202 & \\
\hline$c_{9}$ & 0.240 & 0.222 & 0.203 & 0.268 & 0.179 & 0.254 & 0.298 & 0.258 & & 0.214 & 0.230 & \\
\hline$c_{10}$ & 0.222 & 0.212 & 0.195 & 0.266 & & 0.250 & 0.304 & 0.233 & 0.194 & & 0.220 & \\
\hline$d_{11}$ & 0.206 & 0.181 & & 0.249 & & 0.223 & 0.267 & 0.190 & & 0.186 & & 0.184 \\
\hline$e_{12}$ & & & & 0.227 & & 0.175 & 0.258 & 0.184 & & & 0.194 & \\
\hline
\end{tabular}

Source: Own study.

\section{Results and Discussion}

Table 3 portrays the computation of the direct and indirect influence of the variables in step 4 with a threshold value of 0.173 . Based on Table 3 , the importance of the criteria can be prioritised as $b_{7}>a_{4}>b_{8}>d_{11}>b_{6}>c_{10}>c_{9}>a_{3}>$ $a_{5}>a_{1}>a_{2}>e_{12}$ grounded on the values of $(r+c)$. According to the order of importance of the criteria, frequency of interaction $\left(b_{7}\right)$, was identified as the most important criterion with a value of 5.179, whereas, co-creation task was the least with a value of 2.892 . On the other hand, density $\left(a_{3}\right)$; trust $\left(a_{5}\right)$; commitment 
Table 6. Significant indicators of the variables.

\begin{tabular}{ccccc}
\hline $\mathrm{n}$ & $\mathrm{R}$ & $\mathrm{C}$ & Significant indicator $(\mathrm{R}+\mathrm{C})$ & Relationship indicator $(\mathrm{R}-\mathrm{C})$ \\
\hline $\mathrm{a}_{1}$ & 1.524 & 2.164 & 3.688 & -0.640 \\
$\mathrm{a}_{2}$ & 1.442 & 2.086 & 3.528 & -0.644 \\
$\mathrm{a}_{3}$ & 2.010 & 1.865 & 3.874 & 0.145 \\
$\mathrm{a}_{4}$ & 2.033 & 2.700 & 4.733 & -0.668 \\
$\mathrm{a}_{5}$ & 2.014 & 1.678 & 3.692 & 0.336 \\
$\mathrm{~b}_{6}$ & 1.907 & 2.525 & 4.432 & -0.619 \\
$\mathrm{~b}_{7}$ & 2.224 & 2.955 & 5.179 & -0.731 \\
$\mathrm{~b}_{8}$ & 2.391 & 2.281 & 4.672 & 0.110 \\
$\mathrm{c}_{9}$ & 2.582 & 1.564 & 4.146 & 1.018 \\
$\mathrm{c}_{10}$ & 2.474 & 1.820 & 4.295 & 0.654 \\
$\mathrm{~d}_{11}$ & 2.329 & 2.260 & 4.589 & 0.069 \\
$\mathrm{e}_{12}$ & 1.931 & 0.961 & 2.892 & 0.970 \\
\hline
\end{tabular}

Source: Own study.

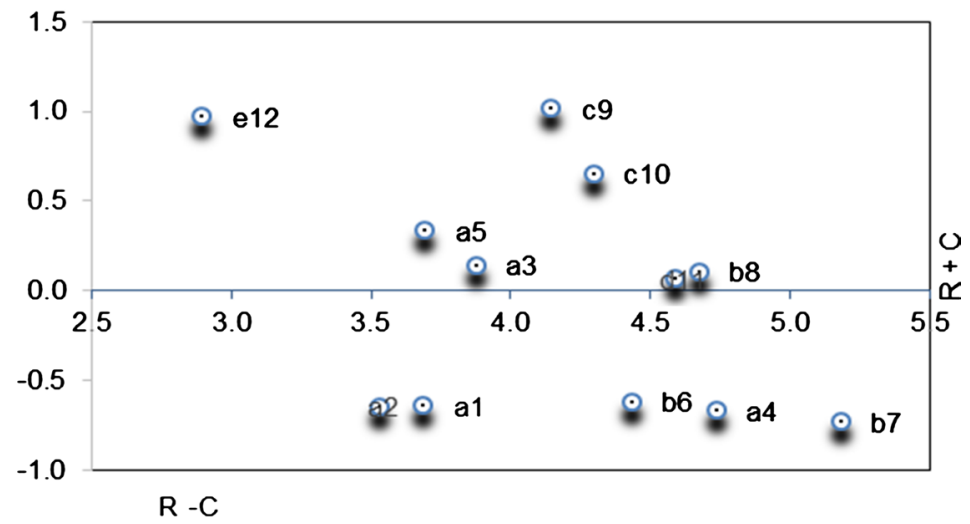

Source: Own study.

Figure 2. Interactive matrix distribution of the 12 criteria.

$\left(b_{6}\right)$; shared codes and language $\left(c_{9}\right)$; Shared narratives $\left(c_{10}\right)$; stakeholder's engagement $\left(\mathrm{d}_{11}\right)$, and co-creation task $\left(\mathrm{e}_{12}\right)$ were identified as causes, whereas network ties $\left(a_{1}\right)$; network size $\left(a_{2}\right)$; social interaction $\left(a_{4}\right)$; frequency of interaction $\left(b_{7}\right)$ were the effects based on $(r-c)$ values. In the digraph (i.e. Figure 2$)$, the values plotted on the horizontal axis were based on the $(r+c)$ value and those on the vertical axis the $(r-c)$ values. According to [90], the digraph simplifies complex causal relationships into understandable visual structures built on the positions of the coordinate $(\mathrm{r}+\mathrm{c})$ and $(\mathrm{r}-\mathrm{c})$, which are categorized into four (4):

- If $(r-c)$ is positive and $(r+c)$ is large, then the attributes are causes and the main drivers for problem resolving. Variables within this group are high in relations and in prominence. These are the core influential variables on other criteria. This consist of commitment $\left(b_{8}\right)$, Shared code and language $\left(c_{9}\right)$, 
shared narratives $\left(c_{10}\right)$, consumer engagement $\left(d_{11}\right)$, density $\left(a_{3}\right)$ and structural holes $\left(\mathrm{a}_{5}\right)$.

- If $(r-c)$ is positive and $(r+c)$ is small, then an indication attributes are independent and can affect few other attributes. It consists of criteria with high relations and low prominence: This is made up co-creation task $\left(\mathrm{e}_{12}\right)$.

- If $(r-c)$ is negative and $(r+c)$ is large: then attributes are the core subject and needs maximum attention; nevertheless, they are effect-type attributes, and cannot be directly improved. It consists of frequency of interaction $\left(b_{7}\right)$, trust $\left(b_{6}\right)$, social interaction $\left(a_{4}\right)$ and network ties $\left(a_{1}\right)$.

- If $(r-c)$ is negative and $(r+c)$ is small: then, an indication that the features are independent and its effects on other attributes are less. This involves network size $\left(a_{2}\right)$.

Taking the foreknown analysis into account, the level and the direction of influence of category one shows that relationships geared toward offering greater value on task must be foundered on value-based commitment to increase the connection and cooperation of actors to induce joint efforts [91]. Consequently, there is a reason to believe that, commitment can persuade actors within a social system to share information and pursue joint expectations of a team via shared code and language, and shared narratives. Shared code and language, and shared narratives bring a common understanding of product/service-related ideas while improving coordination and integration of actors from diverse backgrounds. It also ensures established grammar and vocabulary for communication thereby, resulting in a deeper involvement of the consumer by virtue of task-related and personal interaction with others within the network.

With reference to network density and structural holes, according to [13], these two dimensions are the most debated issues in social networks due to it opposing views on value creation. While density propagate network cohesion and partners connectedness leading to high-quality and easy information distribution in a dense network increasing value creation chances, structural holes look at the disconnection between actors and exposing them to new networks with diverse experiences and different ideas, which offers them (actors) superior information, opportunities and the possibility of manipulating information flow between disconnected parties for their benefits [64]. Although both views differ, yet, since, in value co-creation situation, information and knowledge are the primary and major input, it is then logical to assume structural holes to be a threshold for knowledge heterogeneity.

In category two, co-creation task can produce outcomes that promote high creativity if it unearths customers interest otherwise its importance is insignificant. This should be the focus of firms to make co-creation pay-off.

According to the third category, frequency of interaction $\left(b_{7}\right)$, trust $\left(b_{6}\right)$, social interaction $\left(a_{4}\right)$ and network ties $\left(a_{1}\right)$ cannot be directly improved unless other factors which are also key facilitators to consumer engagement in value creation have been developed. Firms should ensure co-creation tasks are geared toward the interest of the consumer to improve the criteria. 
Lastly, category four indicates a significant influence on social interaction $\left(a_{4}\right)$ and frequency of interaction $\left(b_{7}\right)$.

\section{Conclusions}

In this study, we described the concept and the dimensions of social capital and discussed it influence on consumer engagement to co-create. The social capital dimensions examined were network ties, size, density, social interaction, structural holes, trust frequency of interaction, commitment, shared codes and language and shared narratives which also included consumer engagement and co-creation task. To examine the dimensions on consumer engagement to co-creation, DEMATEL model was applied. The model aided in analyzing the causal relationships of the variables and helped determine their level of interactive effect and direction.

Lastly, the core criteria which were critical for promoting co-creation tasks success were identified. The criteria identified to be crucial in influencing other criteria, and the driving factors for problem resolving were commitment $\left(\mathrm{b}_{8}\right)$, Shared code and language $\left(c_{9}\right)$, shared narratives $\left(c_{10}\right)$, consumer engagement $\left(d_{11}\right)$, density $\left(a_{3}\right)$ and structural holes $\left(a_{5}\right)$ and the core criteria that need maximum attention because they are effect-type attributes, and cannot be directly improved unless through other criteria were frequency of interaction $\left(b_{7}\right)$, trust $\left(b_{6}\right)$, social interaction $\left(a_{4}\right)$ and network ties $\left(a_{1}\right)$.

\section{Conflicts of Interest}

The authors declare no conflicts of interest regarding the publication of this paper.

\section{References}

[1] Pavlovich, K. and Kearins, K. (2004) Structural Embeddedness and Community-Building through Collaborative Network Relationships. Management, 7, 195-214.

[2] Coleman, J.S. (1988) Social Capital in the Creation of Human Capital. American Journal of Sociology, 94, 94-120. https://doi.org/10.1086/228943

[3] Granovetter, M. (1985) Economic Action and the Problem of Embeddedness. American Journal of Sociology, 91, 481-510. https://doi.org/10.1086/228311

[4] Nahapiet, J. and Ghoshal, S. (1998) Social Capital, Intellectual Capital, and Organizational Advantage. Academy of Management Review, 23, 242-266. https://doi.org/10.5465/amr.1998.533225

[5] Putnam, R.D. (1993) Making Democracy Work. Making Democracy Work: Civic Traditions in Modern Italy. Princeton University Press, Princeton, USA.

[6] Woolcock, M. (1998) Social Capital and Economic Development: Toward a Theoretical Synthesis and Policy Framework. Theory and Society, 27, 151-208.

https://doi.org/10.1023/A:1006884930135

[7] Perkins, D.D., Hughey, J. and Speer, P.W. (2002) Community Psychology Perspectives on Social Capital Theory and Community Development Practice. Journal of the Community Development Society, 33, 33-52.

https://doi.org/10.1080/15575330209490141 
[8] Orford, J. (2005) Social Capital: Is It a Good Idea? Clinical Psychology, 153, 11-16.

[9] Novak, D. and Kawachi, I. (2015) Influence of Different Domains of Social Capital on Psychological Distress among Croatian High School Students. International Journal of Mental Health Systems, 9, 18. https://doi.org/10.1186/s13033-015-0010-1

[10] Wallis, J., Killerby, P. and Dollery, B. (2004) Social Economics and Social Capital. International Journal of Social Economics, 31, 239-258. https://doi.org/10.1108/03068290410518238

[11] Dasgupta, P. (2005) Economics of Social Capital. Economic Record, 81, 2-21. https://doi.org/10.1111/j.1475-4932.2005.00245.x

[12] Andersson, M., Larsson, J.P. and Wernberg, J. (2016) Social Capital and the Economics of Cities. In: Westlund, H. and Larsson, J., Eds., Handbook of Social Capital and Regional Development, Edward Elgar Publishing, Cheltenham, 166-192. https://doi.org/10.4337/9781783476831.00012

[13] Zheng, W. (2010) A Social Capital Perspective of Innovation from Individuals to Nations: Where Is Empirical Literature Directing Us. International Journal of Management Reviews, 12, 151-183. https://doi.org/10.1111/j.1468-2370.2008.00247.x

[14] Adler, P.S. and Kwon, S.W. (2001) Social Capital: Prospects for A New Concept. Academy of Management Review, 27, 17-40. https://doi.org/10.5465/amr.2002.5922314

[15] Reagans, R. and Zuckerman, E.W. (2001) Networks, Diversity, and Productivity: The Social Capital of Corporate R\&D Teams. Organization Science, 12, 502-517. https://doi.org/10.1287/orsc.12.4.502.10637

[16] Granovetter, M.S. (1973) The Strength of Weak Ties. American Journal of Sociology, 78, 1360-1380. https://doi.org/10.1086/225469

[17] Liu, T.H., Lo, S.H. and Dai, C.Y. (2018) Expanding the Two Wings of Social Capital for Value Creation: Strategic Entrepreneurship of HTC, 1997-2008. Technology Analysis and Strategic Management, 30, 512-523. https://doi.org/10.1080/09537325.2017.1338683

[18] Bjørnskov, C. and Sønderskov, K.M. (2013) Is Social Capital a Good Concept? Social Indicators Research, 114, 1225-1242.

[19] Tsai, W. and Ghoshal, S. (1998) Social Capital and Value Creation: The Role of Interfirm Networks. Academy of Management Journal, 41, 464-476.

[20] Uzzi, B. (1997) Social Structure and Competition in Interfirm Networks : The Paradox of Embeddedness. Administrative Science Quarterly, 42, 35-67. https://doi.org/10.2307/2393808

[21] Pérez-Luño, A., Cabello Medina, C., Carmona Lavado, A. and Cuevas Rodríguez, G. (2011) How Social Capital and Knowledge Affect Innovation. Journal of Business Research, 64, 1369-1376. https://doi.org/10.1016/j.jbusres.2011.01.014

[22] Camps, S. and Marques, P. (2014) Exploring How Social Capital Facilitates Innovation: The Role of Innovation Enablers. Technological Forecasting and Social Change, 88, 325-348. https://doi.org/10.1016/j.techfore.2013.10.008

[23] Shin, D.J., You, H.J. and Lee, S.K. (2015) Study on the Effects of Follow-Up Consulting Service on Perceived Reciprocity, Corporate Trust and Relational Embeddedness. Indian Journal of Science and Technology, 8, 251-262. https://doi.org/10.17485/ijst/2015/v8iS7/69992

[24] Iturrioz, C., Aragón, C. and Narvaiza, L. (2015) How to Foster Shared Innovation within SMEs' Networks: Social Capital and the Role of Intermediaries. European 
Management Journal, 33, 104-115. https://doi.org/10.1016/j.emj.2014.09.003

[25] Bourdieu, P. (1986) The Forms of Capital. In: Richardson, J., Eds., Handbook of Theory and Research for the Sociology of Education, Greenwood, Westport, 241-258.

[26] Bourdieu, P. and Wacquant, L.J. (1992) The Practice of Reflexive Sociology. An Invitation to Reflexive Sociology, University of Chicago Press, Chicago.

[27] Coleman, J.S. (1987) Families and Schools. Educational Researcher, 16, 32-38. https://doi.org/10.3102/0013189X016006032

[28] Coleman, J.S. (1992) The Vision of Foundations of Social Theory. Analyse \& Kritik, 14, 117-128. https://doi.org/10.1515/auk-1992-0201

[29] Coleman, J.S. (1994) Foundation of Social Theory. Harvard University Press, Cambridge.

[30] Putnam, R.D. (1995) Tuning in, Tuning Out: The Strange Disappearance of Social Capital in America. Political Science and Politics, 28, 664-683. https://doi.org/10.1017/S1049096500058856

[31] Putnam, R.D. (2000) Bowling Aalone: The Collapse and Revival of American Community. Organization, 6, 1-18.

[32] Scrivens, K. and Smith, C. (2013) Four Interpretations of Social Capital: An Agenda for Measurement. OECD Statistics Working Papers No. 2013/06, OECD Publishing, Paris.

[33] Tang, X., Rai, A. and Wareham, J. (2011) Bridging and Bonding in Exchange Networks: A Structural Embeddedness Perspective of B2B Digital Intermediation. IEEE Transactions on Engineering Management, 58, 4-20. https://doi.org/10.1109/TEM.2010.2058852

[34] Ravindran, K., Susarla, A., Mani, D. and Gurbaxani, V. (2015) Social Capital and Contract Duration in Buyer-Supplier Networks for Information Technology Outsourcing. Information Systems Research, 26, 243-472. https://doi.org/10.1287/isre.2015.0572

[35] Bowden, J.L.-H., Conduit, J., Hollebeek, L., Luoma-aho, D.V. and Solem, B.A.A. (2018) The Role of Social Capital in Shaping Consumer Engagement within Online Brand Communities. In: Johnston, K.A. and Taylor, M., Eds., The Handbook of Communication Engagement, John Wiley \& Sons Inc., New York, 491-504. https://doi.org/10.1002/9781119167600.ch33

[36] Chua, A. (2002) The Influence of Social Interaction on Knowledge Creation. Journal of Intellectual Capital, 3, 375-392. https://doi.org/10.1108/14691930210448297

[37] Chiu, M.-H. and Wang, E.T. (2006) Understanding Knowledge Sharing in Virtual Communities: An Integration of Social Capital and Social Cognitive Theories. Decision Support Systems, 42, 1872-1888. https://doi.org/10.1016/j.dss.2006.04.001

[38] Prahalad, C.K. and Ramaswamy, V. (2004) Co-Creating Unique Value with Customers. Strategy \& Leadership, 32, 4-9. https://doi.org/10.1108/10878570410699249

[39] Vargo, S.L., Maglio, P.P. and Akaka, M.A. (2008) On Value and Value Co-Creation: A Service Systems and Service Logic Perspective. European Management Journal, 26, 145-152. https://doi.org/10.1016/j.emj.2008.04.003

[40] Grönroos, C. and Voima, P. (2013) Critical Service Logic: Making Sense of Value Creation and Co-Creation. Journal of the Academy of Marketing Science, 41, 133-150. https://doi.org/10.1007/s11747-012-0308-3

[41] Skålén, P. and Edvardsson, B. (2016) Transforming from the Goods to the Service-Dominant Logic. Marketing Theory, 16, 101-121. 
https://doi.org/10.1177/1470593115596061

[42] Lepak, D.P., Smith, K.G. and Taylor, M.S. (2007) Value Creation and Value Capture: A Multilevel Perspective. Academy of Management Review, 32, 180-194. https://doi.org/10.5465/amr.2007.23464011

[43] Grönroos, C. (2017) On Value and Value Creation in Service: A Management Perspective. Journal of Creating Value, 3, 125-141. https://doi.org/10.1177/2394964317727196

[44] Akaka M.A. and Vargo, S.L. (2014) Technology as an Operant Resource in Service (Eco)Systems. Information Systems and e-Business Management, 12, 367-384. https://doi.org/10.1007/s10257-013-0220-5

[45] Nusenu, A.A., Xiao, W. and Opata, C.N. (2018) U\&G Model as an Antecedent to Ascertain Consumer Level of Participation in Online Value Cocreation. IEEE 7 th International Conference on Adaptive Science \& Technology, Accra, 21-24 August 2018, 1-7. https://doi.org/10.1109/ICASTECH.2018.8507127

[46] Lee, S.M. Olson, D.L. and Trimi, S. (2012) Co-Innovation: Convergenomics, Collaboration, and Co-Creation for Organizational Values. Management Decision, 50, 817-831. https://doi.org/10.1108/00251741211227528

[47] Yli-Renko, H., Autio, E. and Sapienza, H.J. (2012) Social Capital, Knowledge Acquisition, and Knowledge Exploitation in Young Technology-Based Firms. Strategic Management Journal, 22, 587-613. https://doi.org/10.1002/smj.183

[48] Huysman, M. and de Wit, D. (2004) Practices of Managing Knowledge Sharing: towards a Second Wave of Knowledge Management. Knowledge and Process Management, 11, 81-92. https://doi.org/10.1002/kpm.192

[49] Van den Hooff, B. and Huysman, M. (2009) Managing Knowledge Sharing: Emergent and Engineering Approaches. Information \& Management, 46, 1-8. https://doi.org/10.1016/j.im.2008.09.002

[50] Cristina De Oliveira Gobbo, S., Paulo, J., Fusco, A., Alcides, J. and Junior, G. (2014) An Analysis of Embeddedness in the Value Creation in Interorganisational Networks: An Illustrative Example in Brazil. International Journal of Advanced Operations Management, 6, 178-198. https://doi.org/10.1504/IJAOM.2014.061447

[51] Gilsing, V. and Nooteboom, B. (2005) Density and Strength of Ties in Innovation Networks: An Analysis of Multimedia and Biotechnology. European Management Review, 2, 179-197. https://doi.org/10.1057/palgrave.emr.1500041

[52] Walker, G., Kogut, B. and Shan, W. (1997) Social Capital, Structural Holes and the Formation of an Industry Network. Organization Science, 8, 109-125. https://doi.org/10.1287/orsc.8.2.109

[53] Chiu, C.-M., Hsu, M.-H. and Wang, E.T.G. (2006) Understanding Knowledge Sharing in Virtual Communities: An Integration of Social Capital and Social Cognitive Theories. Decision Support Systems, 42, 1872-1888. https://doi.org/10.1016/j.dss.2006.04.001

[54] Hassan, D. and Nikbakhsh, R. (2010) Studying The Relations of Social Capital Factors with Knowledge Sharing. Transylvanian Review of Administrative Sciences, 28-47.

[55] Burt, R.S., Jannotta, J.E. and Mahoney, J.T. (1998) Personality Correlates of Structural Holes. Social Networks, 20, 63-87. https://doi.org/10.1016/S0378-8733(97)00005-1

[56] Seibert, S. E. Kraimer, M. L. and Liden, R. C. (2001) A social capital theory of career success. Academy of Management Journal, 44, 219-237. 
[57] Levin, D.Z., Walter, J., Appleyard, M.M. and Cross, R. (2016) Relational Enhancement: How the Relational Dimension of Social Capital Unlocks the Value of Network-Bridging Ties. Group and Organization Management, 41, 415-457. https://doi.org/10.1177/1059601115574429

[58] McLure Wasko, M. and S. Faraj, W. (2005) Why Should I Share? Examining Social Capital and Knowledge Contribution in Electronic Networks of Practice. MIS Quarterly, 29, 35-57. https://doi.org/10.2307/25148667

[59] Vinerean, S., Opreana, A. and Țichindelean, M. (2014) Analyzing Consumer Engagement Programs from the Perspective of a Qualitative Research of Marketing Executives. Procedia Economics and Finance, 16, 621-630. https://doi.org/10.1016/S2212-5671(14)00849-1

[60] Van Doorn, J., et al. (2010) Customer Engagement Behavior: Theoretical Foundations and Research Directions. Journal of Service Research, 12, 253-266. https://doi.org/10.1177/1094670510375599

[61] Brodie, R.J., Ilic, A., Juric, B. and Hollebeek, L. (2013) Consumer Engagement in a Virtual Brand Community: An Exploratory Analysis. Journal of Business Research, 66, 105-114. https://doi.org/10.1016/j.jbusres.2011.07.029

[62] Verleye, K. (2015) The Co-Creation Experience from the Customer Perspective: Its Measurement and Determinants. Journal of Service Management, 26, 321-342. https://doi.org/10.1108/JOSM-09-2014-0254

[63] Finsterwalder, J. and Kuppelwieser, V.G. (2011) Co-Creation by Engaging beyond Oneself: The Influence of Task Contribution on Perceived Customer-to-Customer Social Interaction during a Group Service Encounter. Journal of Strategic Marketing, 19, 607-618. https://doi.org/10.1080/0965254X.2011.599494

[64] Burt, R.S. (1992) Structural Holes: The Social Structure of Competition. Harvard University Press, Cambridge, No. 1, 58.

[65] Ilic, A., Brodie, R.J. Hollebeek, L.D. and Juric, B. (2011) Customer Engagement: Conceptual Domain, Fundamental Propositions, and Implications for Research. Journal of Service Research, 17, 1-20.

[66] Gummerus, J., Liljander, V., Weman, E. and Pihlström, E. (2012) Customer Engagement in a Facebook Brand Community. Management Research Review, 35, 857-877. https://doi.org/10.1108/01409171211256578

[67] Zhang, M., Guo, L., Hu, M. and Liu, K. (2017) Influence of Customer Engagement with Company Social Networks on Stickiness: Mediating Effect of Customer Value Creation. International Journal of Information Management, 37, 229-240. https://doi.org/10.1016/j.ijinfomgt.2016.04.010

[68] Gulati, R. (1998) Alliances and Networks. Strategic Management Journal, 19, 293-317. https://doi.org/10.1002/(SICI)1097-0266(199804)19:4<293::AID-SMJ982>3.0.CO;2-M

[69] Hansen, M.T. (1999) The Search-Transfer Problem: The Role of Weak Ties in Sharing Knowledge across Organization Subunits. Administrative Science Quarterly, 44, 82-85. https://doi.org/10.2307/2667032

[70] Teece, D.J. (1986) Profiting from Technological Innovation: Implications for Integration, Collaboration, Licensing and Public Policy. Research Policy, 15, 285-305. https://doi.org/10.1016/0048-7333(86)90027-2

[71] Krackhardt, D. (1992) The Strength of Strong Ties: The Importance of Philos in Organizations. Networks and Organizations. Structure, Form, and Action, 216, 239.

[72] Rost, K. (2011) The Strength of Strong Ties in the Creation of Innovation. Research Policy, 40, 588-604. https://doi.org/10.1016/j.respol.2010.12.001 
[73] Shieh, J.-I., Wu, H.-H. and Huang, K.-K. (2010) A DEMATEL Method in Identifying Key Success Factors of Hospital Service Quality. Knowledge-Based Systems, 23, 277-282. https://doi.org/10.1016/j.knosys.2010.01.013

[74] Tzeng, G.H., Chiang, C.H. and Li, C.W. (2007) Evaluating Intertwined Effects in E-Learning Programs: A Novel Hybrid MCDM Model Based on Factor Analysis and DEMATEL. Expert Systems with Applications, 32, 1028-1044.

https://doi.org/10.1016/j.eswa.2006.02.004

[75] Lee, Y.C., Hsieh, Y.F. and Guo, Y. (2013) Construct DTPB Model by Using DEMATEL: A Study of a University Library Website. Program, 47, 155-169. https://doi.org/10.1108/00330331311313744

[76] Dey, S., Kumar, A., Ray, A. and Pradhan B.B. (2012) Supplier Selection: Integrated Theory Using DEMATEL and Quality Function Deployment Methodology. Procedia Engineering, 38, 2111-2116. https://doi.org/10.1016/j.proeng.2012.06.253

[77] Hsu, C.-W., Kuo, T.-C., Chen, S.-H. and Hu, A.H. (2013) Using DEMATEL to Develop a Carbon Management Model of Supplier Selection in Green Supply Chain Management. Journal of Cleaner Production, 56, 164-172. https://doi.org/10.1016/j.jclepro.2011.09.012

[78] Wu, H.-H. and Chang, S.-Y. (2015) A Case Study of Using DEMATEL Method to Identify Critical Factors in Green Supply Chain Management. Applied Mathematics and Computation, 256, 394-403. https://doi.org/10.1016/j.amc.2015.01.041

[79] Leksono, E.B. and Vanany, I. (2018) Using DEMATEL Approach to Develop Relationships of Performance Indicators on Sustainable Service Only Supply Chain Performance Measurement. IOP Conference Series: Materials Science and Engineering, 337, Article ID: 012023. https://doi.org/10.1088/1757-899X/337/1/012023

[80] Wu, J. (2012 ) Analysis the Factors of Enterprise Education Based on DEMATEL Methods. World Automation Congress, Puerto Vallarta, 24-28 June 2012, 1-4.

[81] Ranjan, R., Chatterjee, P. and Chakraborty, S. (2015) Evaluating Performance of Engineering Departments in an Indian University Using DEMATEL and Compromise Ranking Methods. OPSEARCH, 52, 307-328. https://doi.org/10.1007/s12597-014-0186-1

[82] Bahadori, M., Ravangard, R. and Asghari, B. (2013) Perceived Barriers Affecting Access to Preventive Dental Services: Application of DEMATEL Method. Iranian Red Crescent Medical Journal, 15, 655-662. https://doi.org/10.5812/ircmj.11810

[83] Yang, C.H., Chen, J.C. Shyu, J.Z. and Tzeng, G.H. (2008) Causal Relationship Analysis Based on DEMATEL Technique for Innovative Policies in SMEs. Portland International Center for Management of Engineering and Technology, Honolulum, 27-31 July 2008, 373-379.

[84] Tan, W.K. and Kuo, C.Y. (2014) Prioritization of Facilitation Strategies of Park and Recreation Agencies through DEMATEL Analysis. Asia Pacific Journal of Tourism Research, 19, 859-875. https://doi.org/10.1080/10941665.2013.812570

[85] Raghuvanshi, J., Agrawal, R. and Ghosh, P.K. (2017) Analysis of Barriers to Women Entrepreneurship: The DEMATEL Approach. Journal of Entrepreneurship, 26, 220 238. https://doi.org/10.1177/0971355717708848

[86] Chang, K.H., Liaw, C.S., Chang, T.Y. and Chang, Y.C. (2013) FMEA-Based DEMATEl Apportionment Approach. Journal of Chung Cheng Institute of Technology, 42, 41-58.

[87] Muhammad, M.N. and Cavus, N. (2017) Fuzzy DEMATEL Method for Identifying LMS Evaluation Criteria. Procedia Computer Science, 120, 742-749. 
https://doi.org/10.1016/j.procs.2017.11.304

[88] Lin, X.H., Feng, Y.X., Tan, J.R. and An, X.H. (2011) A Hybrid Fuzzy DEMATELVIKOR Method for Product Concept Evaluation. Advanced Materials Research, 186, 230-235. https://doi.org/10.4028/www.scientific.net/AMR.186.230

[89] Chen, J.K. and Chen, I.S. (2010) Using a Novel Conjunctive MCDM Approach Based on DEMATEL, Fuzzy ANP, and TOPSIS as an Innovation Support System for Taiwanese Higher Education. Expert Systems with Applications, 37, 1981-1990. https://doi.org/10.1016/j.eswa.2009.06.079

[90] Tsai, S.-B. (2015) Using the Fuzzy DEMATEL to Determine Environmental Performance: A Case of Printed Circuit Board Industry in Taiwan. PLoS ONE, 10, e0129153. https://doi.org/10.1371/journal.pone.0129153

[91] Sharma, N., Young, L.C. and Wilkinson, I. (2015) The Nature and Role of Different Types of Commitment in Inter-Firm Relationship Cooperation. Journal of Business and Industrial Marketing, 30, 45-59. https://doi.org/10.1108/JBIM-11-2012-0202 